\title{
Epidemiology of Antiphospholipid Syndrome in the General Population
}

\author{
Jesse Y. Dabit ${ }^{1}$ - Maria O. Valenzuela-Almada ${ }^{1} \cdot$ Sebastian Vallejo-Ramos ${ }^{1} \cdot$ Alí Duarte-García $^{1,2}$ \\ Accepted: 10 June 2021 / Published online: 5 January 2022 \\ (C) The Author(s), under exclusive licence to Springer Science+Business Media, LLC, part of Springer Nature 2022
}

\begin{abstract}
Purpose of Review The epidemiology of antiphospholipid syndrome (APS) is poorly understood. Here, we review the current understanding of the epidemiology of antiphospholipid syndrome in the general population and the frequency of antiphospholipid antibodies in the general population in patients with obstetric morbidity, arterial events, and venous thromboembolism.

Recent Findings There have been few population-based studies that estimated the prevalence and incidence of APS. The estimated incidence and prevalence among most these studies ranged between 1 and 2 cases per 100,000 and 40 and 50 cases per 100,000 respectively. The prevalence of antiphospholipid antibodies in patients with obstetric morbidity was 6-9\%, while in arterial events and venous thromboembolism is $9-10 \%$. However, this data remains limited. Mortality of patients with APS is $50-$ $80 \%$ higher than the general population.

Summary The epidemiology of APS has been difficult to elucidate. Population-based studies patients with diverse age, racial, and ethnic backgrounds are needed.
\end{abstract}

Keywords Antiphospholipid syndrome · Epidemiology

\section{Introduction}

Antiphospholipid syndrome (APS) is a systemic autoimmune disease characterized by obstetric morbidity, arterial and/or venous thrombosis in the presence of antiphospholipid antibodies

Jesse Y. Dabit and Maria O. Valenzuela-Almada contributed equally to this work.

This article is part of the Topical Collection on Antiphospholipid Syndrome

Alí Duarte-García

duarte.ali@mayo.edu

Jesse Y. Dabit

dabit.jesse@mayo.edu

Maria O. Valenzuela-Almada

ValenzuelaAlmada.Maria@mayo.edu

Sebastian Vallejo-Ramos

vallejo.sebastian1@mayo.edu

1 Division of Rheumatology, Mayo Clinic, Rochester, MN, USA

2 Robert D. and Patricia E. Kern Center for the Science of Health Care Delivery, Mayo Clinic, 200 First Street SW, Rochester, MN 55905, USA
(aPL). APS is often classified as primary when it is not associated with other autoimmune diseases or as secondary when it is. APS is most associated with systemic lupus erythematosus (SLE) [1].

In 1998, the Sapporo criteria were introduced to classify APS cases. Accordingly, an APS case is classified when at least one clinical criterion and at least one laboratory criterion are present [2]. Clinical criteria included either pregnancy morbidity or vascular thrombosis. The laboratory criteria included the presence of medium or high titers of IgG and/or IgM of anticardiolipin (aCL) and/or lupus anticoagulant (LAC) on two or more occasions at least 6 weeks apart. In 2006, the revised Sapporo criteria (also called Sydney criteria) added the IgG/IgM anti-beta 2 glycoprotein 1 (anti- $\beta_{2} \mathrm{GPI}$ ) antibody test to the laboratory criteria and the interval between positive tests was prolonged from 6 to 12 weeks [3].

There are other clinical manifestations of APS which are not included in the current classification criteria, the so-called "non-criteria" manifestations [4]. These manifestations include thrombocytopenia, APS-associated nephropathy, valvular heart disease, livedo reticularis, cognitive impairment, and others [4]. Additionally, other autoantibodies such as IgA isotypes (IgA aCL and IgA anti- $\beta_{2}$ GPI), and phosphatidylserine/prothrombin complex autoantibodies (aPS/PT), among others, have been reported but their clinical 
relevance is currently debated [4,5]. Currently the inclusion of some of these manifestations and novel autoantibodies into the classification criteria is being considered.

The epidemiology of APS has been difficult to elucidate. With an ever-evolving classification criteria, new autoantibodies, and increased awareness, patients with previously unrecognized APS may now be identified. In this review, we summarized the current literature regarding the incidence and prevalence of APS in the general population and the frequency of positive aPL in the general population and among those with arterial or venous thrombosis, and pregnancy morbidity.

\section{Epidemiology of Antiphospholipid Syndrome in the General Population}

Estimating the frequency of APS has been challenging given the changes in the definition of the APS classification criteria, the lack of standardization to detect aPL, differences in laboratory cutoffs, and other difficulties such as confirming aPL positivity 12 weeks after the initial measurement.

The epidemiological data remains limited, but the characterization of the incidence and prevalence of APS in the general population has improved with several new publications in the recent years. For this review and given the paucity of data, we included data presented in international conferences that has not been published yet. There have been six studies estimating the frequency of APS in the general population, one from the USA, one from South America, one from Asia, and three from Europe (Table 1). The studies have used different methodologies or population samples, some relying on the use of diagnostic codes as case definition while others relied on medical record review and current classification criteria. Few studies have been population-based, while others have been based on regional registries or health management organizations.

The first study to report the incidence and prevalence of APS was from the USA. In this study, a population-based cohort of newly diagnosed APS patients from 2000 to 2015 in Olmsted County, Minnesota, was assembled. This study used the Rochester epidemiology project, a record-linkage system that captures virtually all the APS cases in Olmsted County. The Sydney 2006 criteria were used as case definition, and cases were confirmed by medical record review. The reported annual incidence of APS was 2.1 per 100,000, while the estimated prevalence was 50 per 100,000 population [6••]. This cohort was predominantly White $(97 \%)$, and the total number of incident cases was low. Given the close association of SLE with APS, it is possible that - as observed in SLEthere are differences in the frequency, clinical characteristics, and complications of APS among different races and ethnicities that this study did not capture.
The Argentinian study was presented during the American College of Rheumatology Scientific Meeting in 2018. The study population was a health management organization from 2000 to 2015. APS cases were included if they met the 2006 Sydney criteria. The overall incidence rate was 2.6 cases per 100,000 , and the overall prevalence rate was 40.5 per 100,000 . This was similar to the findings from the US study. These findings have not been published in a peer-review publication [7].

The study from South Korea analyzed nation-wide claims data from 2008 to 2017. The definition of APS was a clever use of diagnostic and healthcare utilization codes. The study defined a case as an individual with an APS-related code in addition to two codes documenting aPL testing and prescription of anticoagulants. The estimated incidence in this study was 0.75 cases per 100,000 , and the prevalence was 6.19 per 100,000 [8]. The incidence and prevalence of APS in this study was remarkably lower than in the studies from the USA or Europe. It is unclear if this difference is due to the different racial background of the populations or due to the strict definition used to identify the cases. This claims definition of APS has not been validated.

There have been three studies from Europe with all of them estimating prevalence and only two estimated the incidence. In a letter to the editor by Radin et al., the frequency of APS in the Piedmont and Aosta Valley regions (northwest Italy) was reported using the Regional Rare Disease Registry. The prevalence of APS was 16.8 per 100,000, and the annual incidence rate was 1.1 per 100,000 population [9]. The reported prevalence in this study was lower than most of the other studies. It is unknown if all the APS cases from the region are captured by the registry which could have led to the prevalence rate underestimation.

Data from the United Kingdom (UK) was presented during the American College of Rheumatology Scientific Meeting in 2019 by Rodziewicz et al. Using UK Clinical Practice Research Datalink (CPRD), a UK population health dataset, they identified patients with APS from 1990 to 2016 using Read codes. The peak APS incidence was 7.5 per 100,000 women between ages 35 and 39, while the peak APS incidence for men was 2.2 per 100,000 between ages 55 and 59 . The prevalence was 50 per 100,000 in females and 9.8 per 100,000 in males. Overall incidence and prevalence were not reported. These findings have not been published in a peerreviewed publication and the APS Read codes have not been validated yet [10].

The last study available from Europe used a large dataset from Catalonia in Spain to identify patients with autoimmune diseases including APS. From 2012 to 2017, they identified patients with autoimmune diseases based on the presence of one or more ICD-9 codes. The estimated prevalence of APS was 40 per 100,000 in Catalonia. A limitation of this study is the lack of a validated ICD-9 code to identify patients with 
Table 1 Data on APS incidence and prevalence around the world

\begin{tabular}{|c|c|c|c|c|c|c|c|c|}
\hline Author & $\begin{array}{l}\text { Country/ } \\
\text { geographical area }\end{array}$ & $\begin{array}{l}\text { Study } \\
\text { period }\end{array}$ & Case definition & Sample & $\begin{array}{l}\text { Number } \\
\text { of cases }\end{array}$ & $\begin{array}{l}\text { Incidence } \\
\text { per } 100,000 \\
(\mathrm{~F} / \mathrm{M})\end{array}$ & $\begin{array}{l}\text { Prevalence } \\
\text { per } 100,000 \\
(\mathrm{~F} / \mathrm{M})\end{array}$ & $\begin{array}{l}\text { Incidence } \\
\text { peak age (F/ } \\
\text { M) }\end{array}$ \\
\hline $\begin{array}{c}\text { Duarte-Garcia } \\
{[6 \bullet \bullet]}\end{array}$ & $\begin{array}{l}\text { USA/Midwestern } \\
\text { Olmsted county }\end{array}$ & $2000-2015$ & $\begin{array}{l}\text { Sydney } 2006 \\
\text { criteria }\end{array}$ & $\begin{array}{l}\text { Population-based } \\
\text { Record-linkage } \\
\text { system }\end{array}$ & 33 & $2.1(2.1 / 2.0)$ & $50(51 / 48)$ & $75+/ 55-64$ \\
\hline Hwang [8] & South Korea & 2008-2017 & $\begin{array}{l}\text { Diagnostic and } \\
\text { utilization codes } \\
\text { combination }\end{array}$ & $\begin{array}{l}\text { Nationwide } \\
\text { claims } \\
\text { database }\end{array}$ & 3088 & $\begin{array}{l}0.75 \\
\quad(0.91 / 0.5- \\
9)\end{array}$ & $\begin{array}{l}6.19 \\
\quad(7.62 / 4.76)\end{array}$ & $\begin{array}{c}30-39 \text { and } \\
70-79 / 7- \\
0-79\end{array}$ \\
\hline Luissi [7] & Argentina & $2000-2015$ & $\begin{array}{l}\text { Sydney } 2006 \\
\text { criteria }\end{array}$ & $\begin{array}{l}\text { Health } \\
\text { management } \\
\text { organization }\end{array}$ & $\begin{array}{r}53(50 \\
\text { defi- } \\
\text { nite })\end{array}$ & $2.6(2.9 / 2.0)$ & $\begin{array}{l}40.5 \\
\text { (NA/NA) }\end{array}$ & $30-39 / 60-69$ \\
\hline Radin [9] & $\begin{array}{l}\text { Northwest Italy } \\
\text { (Piedmont and } \\
\text { Aosta Valley) }\end{array}$ & 2010-2019 & $\begin{array}{c}\text { Definite APS } \\
\text { diagnoses }\end{array}$ & $\begin{array}{l}\text { Regional rare } \\
\text { disease registry }\end{array}$ & 740 & 1.1 (NA/NA) & $\begin{array}{l}16.8 \\
(\mathrm{NA} / \mathrm{NA})\end{array}$ & NA \\
\hline $\begin{array}{l}\text { Rodziewicz } \\
{[10]}\end{array}$ & UK & 1990-2016 & Diagnostic codes & $\begin{array}{l}\text { Nationwide } \\
\quad \text { claims } \\
\text { database }\end{array}$ & 2606 & $1.8(7.3 / 2.2)^{*}$ & $43(50 / 9.8)^{*}$ & $35-39 / 50-59$ \\
\hline $\begin{array}{l}\text { Siso-Almirall } \\
\text { [11] }\end{array}$ & Spain (Catalonia) & 2012-2017 & ICD9 codes & $\begin{array}{l}\text { Regional } \\
\text { healthcare } \\
\text { database }\end{array}$ & 2999 & NA & 40 (NA/NA) & NA \\
\hline
\end{tabular}

*Peak incidence and prevalence estimates

$F$ female, $M$ male, $A P S$ antiphospholipid syndrome, $I C D$ International Classification of Diseases

APS as the available ICD-9 code includes several primary hypercoagulable conditions besides APS. This study did not report an incidence rate [11].

\section{Impact of Age and Gender on the Frequency of Antiphospholipid Syndrome}

Systemic autoimmune diseases tend to be more frequent in women, and many of them affect patients during midlife or the reproductive years. SLE, for example, is reported to be up to ten times more frequent in women of reproductive age [12]. Given the association of SLE with APS, it is possible that age and gender play a role in the frequency of APS (Table 1).

The mean age of APS diagnosis reported in recent population-based studies is around 50 years [6••, 7-9]. Earlier cohorts reported lower mean age of diagnosis such as in the Euro-phospholipid project and the APS piedmont cohort $[13,14]$. The UK CPRD study reported a peak age for incidence in men of 55-59 years, whereas for women the incidence peaked at 35-39 years [10]. Interestingly, in the Korean nationwide population-based study, the incidence of APS tended to increase with age only in men, peaking at ages of 70-79. In women, the incidence peaked at ages 30-39 and 70-79 [8]. On the other hand, in the US study, the incidence peaked in males at ages 55-64 and at 75+ years in women [6••]. The differences in age when APS incidence peaked could be attributed to different characteristics of the population of each study, including different proportion of primary versus secondary APS and perhaps differences in racial and ethnic backgrounds.

APS incidence peaks tended to be later in life than SLE [15]. The prevalence of aPL and the incidence of thrombotic events increase with age, making it harder to attribute the latter to the presence of aPL. Because of the increased incidence in thrombotic events, aPL may be tested more frequently in the elderly population, thus creating bias in these findings [16].

Childhood APS remains largely uninvestigated. The International Pediatric APS registry and several pediatric APS cohorts have reported a mean diagnosis age of 10 years [17-19]. When breaking down primary and secondary pediatric APS, the former occurs at a younger age while the latter is more common during adolescent years.

There have been conflicting reports regarding the frequency of APS in males and females. For instance, in both the APS piedmont cohort and Euro-Phospholipid cohort, the proportion of women was higher than $70 \%[13,20]$. However, in recent population-based studies, the proportion of female patients has been found to be between 55 and $67 \%$ and the female to male ratio decreases after exclusion of patients with SLE and obstetric APS, reaching close to $1: 1[6 \bullet \bullet, 7,8]$. For example, in the UK CPRD study, the female to male ratio of APS patients with and without SLE was 10:1 and 4:1, respectively [10], whereas in the data from Spain, the overall ratio was 2:1 [11]. In Argentina, Luissi et al. observed a 2:1 female to male ratio with $85 \%$ of their patients having primary APS [7]. In pediatric APS, the female to male ratio is 1.1 [21], while 
on the elderly phospholipid study, there were more males than females with APS [22].

\section{Mortality in Antiphospholipid Syndrome}

The mortality of APS has been shown to be higher than that of the general population both in population-based studies and in referral cohorts. Rodziewicz et al. reported an overall APS standardized mortality ratio (SMR) of 1.49 and 1.33 in females and males, respectively, compared to the UK general population, thus indicating higher mortality rates among APS patients [10]. The study from the USA also reported an SMR among APS patients to be 1.61 compared to the general population, and the 10 -year survival rate was $80 \%$. [6••]. The SMR has been slightly higher in the referral center cohorts. In the Euro-Phospholipid project, a prospective cohort based on multiple referral centers, the 10 -year survival rate was $90.7 \%$ and the unadjusted SMR was 1.8. [20]

\section{Frequency of Antiphospholipid Antibodies in the General Population}

Similarly, to APS, the data regarding the prevalence of aPL in the general population is limited. The available studies have great heterogeneity both in methodology and definitions for aPL positivity. In Table 2, we summarized the data of aPL measurements obtained from healthy individuals since year 2000. Most of the studies have reported an aCL prevalence of any isotype of less than $10 \%$ except for the studies of individuals from the extremes of life. Most of the studies had a higher prevalence of aCL IgG compared to IgM. In general, the prevalence of anti- $\beta_{2}$ GPI in healthy controls has been lower than aCL. Most of the reports have had a prevalence of less than $5 \%$, and similarly to aCL, anti- $\beta_{2} \mathrm{GPI}$ IgG is more frequent than IgM. LAC on the other hand is present in less than $1 \%$ of healthy controls. aCL has been reported to be positive in as many as $50 \%$ in healthy elderly subjects [23]. In a study of centenarians without evidence of autoimmune disease, $54.3 \%$ of the patients were positive for $\operatorname{IgG}$ and $8.6 \%$ for IgM anti- $\beta_{2}$ GPI antibodies, while $20.7 \%$ were positive for aCL-IgG and $2.6 \%$ for aCL-IgM antibodies. None was positive for LAC [24].

The frequency of aPL in children is understudied. Previous reports showed a positivity rate of up to $25 \%$ in asymptomatic healthy children which is usually transient and secondary to infections or vaccination, and most children with positive aPL do not develop symptoms [21, 25].

aPL can be associated with infectious processes. In a metaanalysis of studies reporting frequency of aPL following viral infections, patients with HIV and Epstein-Barr virus were 10 times more likely to develop elevated aCL antibodies compared to healthy controls, while those with hepatitis $\mathrm{C}$ virus
(HCV) and hepatitis B had 6 and 4 times the risk, respectively. $\mathrm{HCV}$ was the only virus associated with an increased risk for developing anti- $\beta_{2}$ GPI compared to healthy controls $(8 \%$ vs $<$ 1\%; RR 4.8) [26]. Recently, coronavirus disease 2019 (COVID-19) infection has been reported to be associated with positive aPL. Among hospitalized patients with COVID-19, LAC has been reported to be positive in as many as $45 \%$ of the patients, while $10 \%$ were positive for either aCL or anti- $\beta_{2} \mathrm{GPI}$ antibodies, with even higher frequencies among those critically ill $[27,28]$.

Bacterial infections have been associated with positive $\mathrm{aCL}$, in particular, syphilis and leprosy. Patients with syphilis have been found to have up to $67 \% \mathrm{aCL}$ while the prevalence of aCL in leprosy ranged from 21 to $67 \%$ [29].

aPL have also been associated with malignancy. A recent systemic review of observational studies reporting aPL frequency among patients with various solid tumors found that patients with gastrointestinal and lung cancers had 5 times the risk to develop aCL compared to healthy controls while those with genitourinary cancers had 7 times the risk [30]. Regarding hematologic malignancies, Pusterla et al. reported among 100 patients with lymphoma, $24 \%$ were positive for aCL while 7\% of them were positive for LAC [31]. Another study reported that patients with lymphoma had a single, double, and triple aPL positivity of $29.9 \%, 5.2 \%$, and $0.6 \%$, respectively [32].

\section{Pregnancy Morbidity and Prevalence of Antiphospholipid Antibodies}

Obstetric morbidity is one of the hallmarks of APS. Recurrent pregnancy loss, fetal death, placental insufficiency, and other adverse pregnancy outcomes have been associated with APS; however, these obstetric manifestations are also common in the general population and are usually multifactorial.

The data evaluating the association between these obstetric outcomes and aPL presence is limited (Table 3). Regarding overall pregnancy loss, Infante-Rivard et al. reported that among women with spontaneous abortion or fetal death, $5.1 \%$ and $1.2 \%$ had positive LAC and aCL, when compared to $3.8 \%$ and $1.5 \%$ in controls, respectively [33]. A review of the literature summarizing 120 full texts between 1984 and 2011 found a median frequency of $8 \%, 5 \%$, and $9.5 \%$ of $\mathrm{aCL}$, anti- $\beta_{2} \mathrm{GPI}$, and LAC, respectively, in women with pregnancy loss. In studies that separated early $(<10$ weeks of gestation) vs late pregnancy loss ( $\geq 10$ weeks of gestation), a median frequency of $4 \%, 2 \%$, and $1 \%$ of aCL, anti- $\beta 2 \mathrm{GPI}$, and LAC was observed, respectively, in early pregnancy loss versus $9 \%, 5 \%$, and $4 \%$ in late pregnancy loss [34•]. Higher frequencies of aPL have been reported in women with recurrent early miscarriage. In women with 2 consecutive early 
Table 2 Frequency of aPL in the general healthy population without APS diagnosis as reported in selected studies since $2000^{1}$

\begin{tabular}{|c|c|c|c|c|c|c|c|c|c|}
\hline Author, year & Subjects & $\begin{array}{l}\mathrm{N} \text { of } \\
\text { subjects }\end{array}$ & $\begin{array}{l}\text { LAC } \\
(\%)\end{array}$ & $\operatorname{aCL}(\%)$ & $\begin{array}{l}\text { aCL- } \\
\operatorname{IgG}(\%)\end{array}$ & $\begin{array}{l}\text { aCL- } \\
\operatorname{IgM}(\%)\end{array}$ & $\begin{array}{l}\text { Anti- } \\
\beta 2 G P I \\
(\%)\end{array}$ & $\begin{array}{l}\text { Anti- } \beta 2 \text { GPI } \\
\text { IgG }(\%)\end{array}$ & $\begin{array}{l}\text { Anti- } \beta 2 \text { GPI } \\
\text { IgM }(\%)\end{array}$ \\
\hline $\begin{array}{l}\text { Siemens, } \\
\quad 2000[53]\end{array}$ & Healthy adults & 200 & NA & 7.3 & NA & NA & 6.7 & NA & NA \\
\hline \multirow{3}{*}{$\begin{array}{l}\text { Rapizzi, } 2000 \\
\text { [54] }\end{array}$} & Healthy children & 100 & NA & $27 *$ & $26^{*}$ & $1^{*}$ & NA & NA & NA \\
\hline & Healthy adults & 100 & NA & $7 *$ & $5 *$ & $2 *$ & NA & NA & NA \\
\hline & Healthy elderly & 100 & NA & $16^{*}$ & $12 *$ & $4 *$ & NA & NA & NA \\
\hline $\begin{array}{l}\text { Ordi-Ros, } \\
2000[55]\end{array}$ & Healthy controls & 100 & NA & 0 & NA & NA & NA & NA & NA \\
\hline $\begin{array}{l}\text { Sthoeger, } \\
2000[56]\end{array}$ & Healthy controls & 50 & NA & 0 & NA & NA & NA & NA & NA \\
\hline $\begin{array}{l}\text { Brey, } 2001 \\
\quad[57]\end{array}$ & Healthy men & 1360 & NA & NA & 12.1 & 4.4 & 1.9 & NA & NA \\
\hline $\begin{array}{l}\text { Brey, } 2002 \\
\quad[44]\end{array}$ & Healthy women & 340 & 12.8 & 18 & 8 & 9 & NA & NA & NA \\
\hline \multirow{2}{*}{$\begin{array}{l}\text { Avcin, } 2001 \\
\quad[58]\end{array}$} & Healthy children & 61 & NA & 11.4 & 11.4 & NA & 6.6 & 3.3 & NA \\
\hline & Blood donors & 52 & NA & 9.6 & 5.7 & NA & 7.7 & 1.9 & NA \\
\hline $\begin{array}{l}\text { Cabiedes, } \\
2001[59]\end{array}$ & Healthy Children & 360 & NA & NA & 2.2 & 4.1 & NA & 3 & 3.3 \\
\hline $\begin{array}{l}\text { Harrison, } \\
2002[60]\end{array}$ & Healthy elderly (> 50 years) & 200 & NA & 2 & 1.5 & 0.5 & NA & 1.5 & 0 \\
\hline $\begin{array}{l}\text { Mclntyre, } \\
2003[61]\end{array}$ & Blood donors & 775 & NA & 2.6 & NA & NA & NA & NA & NA \\
\hline $\begin{array}{l}\text { Palomo, } 2003 \\
\text { [62] }\end{array}$ & Healthy controls & 52 & 0 & 3.8 & NA & NA & 1.9 & NA & NA \\
\hline $\begin{array}{l}\text { Meroni, } 2004 \\
\text { [24] }\end{array}$ & Centenarians & 77 & NA & NA & 20 & 2.5 & NA & 54.3 & 8.6 \\
\hline $\begin{array}{l}\text { Pusterla, } \\
\quad 2004[31]\end{array}$ & Healthy controls & 100 & 1 & 7 & NA & NA & NA & NA & NA \\
\hline $\begin{array}{l}\text { Urbanus, } \\
2009[45]\end{array}$ & Healthy women & 628 & 0.6 & NA & 1 & NA & NA & 1 & NA \\
\hline $\begin{array}{l}\text { Font, } 2011 \\
\quad[63]\end{array}$ & Healthy controls & 8 & 0 & NA & 0 & 0.4 & 0 & 0.4 & 0 \\
\hline $\begin{array}{l}\text { Silver, } 2013 \\
\quad[38]\end{array}$ & $\begin{array}{l}\text { Healthy women with live } \\
\text { births }\end{array}$ & 1547 & NA & NA & 1.1 & 3.1 & NA & 0.6 & 1.9 \\
\hline $\begin{array}{l}\text { Gibbins, } \\
2018 \text { [39] }\end{array}$ & $\begin{array}{l}\text { Healthy women with } \\
\text { uneventful pregnancies }\end{array}$ & 148 & 1.4 & NA & 0 & 2 & 0 & 0 & 0 \\
\hline $\begin{array}{l}\text { Foddai, } 2020 \\
\text { [36] }\end{array}$ & $\begin{array}{l}\text { Healthy women with } \\
\text { uneventful pregnancies }\end{array}$ & 100 & NA & NA & 2 & NA & NA & 1 & NA \\
\hline
\end{tabular}

*Cut-off value for aCL $\operatorname{IgG}$ and $\operatorname{IgM}$ were 11.6 and 7.5 , respectively

LAC Lupus anticoagulant, $a C L$ anticardiolipin antibody, anti- $\beta 2 G P I$ anti-b2 glycoprotein antibodies, USA United States of America

${ }^{1}$ PubMed was utilized to search for antiphospholipid antibodies/aPL and the various complications (malignancy, cancer; general population, healthy, blood donors; infection, HCV, COVID19, viral, bacterial, parasitic). Included only studies that reported the frequency of the different aPL and were published in 2000 or later

miscarriages, $4 \%$ had at least one aPL, compared to $11 \%$ in women with more than 3 recurrent early miscarriages [35].

Consistently with the results of Andreoli et al. high frequencies of aPL among women with late pregnancy loss have also been reported in recent studies [34•, 36-38]. In 582 women with fetal loss at or after 20 weeks of gestation, Silver et al. reported $9.6 \%$ positivity of one or more antibody including $\mathrm{IgG} / \mathrm{IgM}$ aCL and anti- $\beta_{2}$ GPI. Excluding stillbirths associated with fetal anomalies, $11.3 \%$ of patients were positive for at least one aPL [38]. Additionally, in another case-control multicentric study, 3 out of 7 women with stillbirth were positive for at least one aPL [36].

Regarding outcomes associated with placental insufficien$\mathrm{cy}$, the prevalence of aPL positivity in women with late-onset pregnancy complications associated with placental insufficiency is reported to be around $31 \%$, compared to $10 \%$ in those without placental insufficiency [36]. In a recently published case-control study, women having preterm births due to preeclampsia or placental insufficiency were more likely to have positive aPL than controls $11.5 \%$ vs $1.4 \%$. When 
Table 3 Proportion of different comorbidities associated with APS and aPL positivity ${ }^{1}$

\begin{tabular}{|c|c|c|c|c|c|c|c|c|c|}
\hline $\begin{array}{l}\text { Author and } \\
\text { year }\end{array}$ & Subject characteristics & $\begin{array}{l}\mathrm{N} \text { of } \\
\text { subjects }\end{array}$ & $\begin{array}{l}\text { LAC } \\
(\%)\end{array}$ & aCL $(\%)$ & $\begin{array}{l}\text { aCL- } \\
\text { IgG } \\
(\%)\end{array}$ & $\begin{array}{l}\text { aCL- } \\
\text { IgM } \\
(\%)\end{array}$ & $\begin{array}{l}\text { Anti- } \\
\beta 2 G P I \\
(\%)\end{array}$ & $\begin{array}{l}\text { Anti- } \\
\beta 2 G P I \\
\text { IgG }(\%)\end{array}$ & $\begin{array}{l}\text { Anti- } \\
\beta 2 G P I \\
\text { IgM }(\%)\end{array}$ \\
\hline \multicolumn{10}{|c|}{ Obstetric complications } \\
\hline $\begin{array}{l}\text { Infante-Rivard. } \\
\quad 1991[33]\end{array}$ & $\begin{array}{l}\text { Women with spontaneous abortion or fetal } \\
\text { death }\end{array}$ & 331 & 5.1 & NA & 1.2 & NA & NA & NA & NA \\
\hline $\begin{array}{l}\text { Silver, } 2013 \\
\quad[38]\end{array}$ & Mothers of stillbirth deliveries & 582 & NA & NA & 3.8 & 3.4 & NA & 1.9 & 2.7 \\
\hline Bowman, 2015 & $\begin{array}{l}\text { Women with chief complaint of pregnancy loss } \\
\text { (REM, fetal demise, history of SLE or VTE) }\end{array}$ & 338 & 2.4 & NA & 2.4 & 2.1 & NA & 1.5 & 3 \\
\hline $\begin{array}{l}\text { Gibbins, } 2018 \\
\text { [39] }\end{array}$ & $\begin{array}{l}\text { Mothers with preterm delivery due to } \\
\text { preeclampsia with severe features or } \\
\text { placental insufficiency }\end{array}$ & 148 & 8.8 & 5.4 & 1.4 & 4.1 & 2.7 & 0.7 & 2 \\
\hline \multirow{2}{*}{$\begin{array}{l}\text { Benson, } 2019 \\
\quad[35]\end{array}$} & Women with $2<10$ weeks miscarriages & 36 & 2.6 & 0 & 0 & 0 & 2.8 & NA & NA \\
\hline & $\begin{array}{l}\text { Women with } 3 \text { or more }<10 \text { weeks } \\
\text { miscarriages }\end{array}$ & 76 & 1.1 & 0 & 0 & 0 & 13.2 & 5.9 & 7.3 \\
\hline $\begin{array}{l}\text { Foddai, } 2020 \\
\quad[36]\end{array}$ & $\begin{array}{l}\text { Women with late onset pregnancy } \\
\text { complications }\end{array}$ & 100 & NA & NA & 10 & NA & NA & 0 & NA \\
\hline \multicolumn{10}{|l|}{ Thrombosis } \\
\hline \multirow[t]{2}{*}{ Brey, 2001 [57] } & Men of Japanese ancestry with stroke & 259 & NA & NA & 1.5 & 8.7 & 2.2 & 16.6 & 3.6 \\
\hline & Men of Japanese ancestry with MI & 374 & NA & NA & 2.4 & 10.2 & 1.3 & 15.8 & 4.6 \\
\hline Brey, 2002 [44] & Women $15-44$ years old with ischemic stroke & 160 & 20.9 & NA & 14 & 0.6 & NA & NA & NA \\
\hline \multirow[t]{2}{*}{$\begin{array}{l}\text { Urbanus, } 2009 \\
\text { [45] }\end{array}$} & $\begin{array}{l}\text { Women } 18-49 \text { years old with a first ischemic } \\
\text { stroke }\end{array}$ & 175 & 17.1 & NA & 3.6 & NA & NA & NA & NA \\
\hline & Women 18-49 years old with a first MI & 203 & 2 & NA & 1 & NA & NA & NA & NA \\
\hline \multirow[t]{3}{*}{$\begin{array}{l}\text { Chayoua, } 2018 \\
\text { [42] }\end{array}$} & $\begin{array}{l}\text { Patients } 16-87 \text { years old with non-APS } \\
\text { thrombosis/autoimmune controls/other } \\
\text { controls }\end{array}$ & 204 & 0 & $0 * *$ & NA & NA & $0 * *$ & NA & NA \\
\hline & $\begin{array}{l}\text { Patients } 16-87 \text { years old with autoimmune } \\
\text { diseases (non-APS) }\end{array}$ & 196 & 28.6 & 7.1-11** & NA & NA & $7.1-11 * *$ & NA & NA \\
\hline & $\begin{array}{l}\text { Controls } 16-87 \text { years old referred for } \\
\text { subfertility and long PTT }\end{array}$ & 193 & 8.3 & $1.6-3.1 * *$ & $\mathrm{NA}$ & NA & $1.6-3.1 * *$ & NA & NA \\
\hline $\begin{array}{l}\text { Kearon, } 2018 \\
\text { [64] }\end{array}$ & $\begin{array}{l}\text { Patients } 18-50 \text { years old with a first } \\
\text { unprovoked VTE }\end{array}$ & 307 & 26.2 & 8.9 & 4 & 3.7 & 1 & NA & NA \\
\hline $\begin{array}{l}\text { Miranda, } \\
2020^{* * *} \\
{[41 \bullet \bullet]}\end{array}$ & $\begin{array}{l}\text { Patients } 18-50 \text { years old with a first } \\
\text { unprovoked VTE }\end{array}$ & 524 & 3.2 & 6.1 & NA & NA & 3.8 & NA & NA \\
\hline
\end{tabular}

*Median $\%$ among studies included. **Range depending on assay used for triple positivity. ***Percentages calculated for the total number of subjects in the study

$L A C$ lupus anticoagulant, $a C L$ anticardiolipin antibody, anti- $\beta 2 G P I$ anti-b2 glycoprotein antibodies, $M I$ myocardial infarction, $C V E$ cardiovascular event, TIA transient ischemic attack, APS antiphospholipid syndrome, REM recurrent early miscarriage, SLE systemic lupus erythematosus, $P T T$ partial thromboplastin time, VTE venous thromboembolism

${ }^{1}$ PubMed was utilized to search for antiphospholipid antibodies/aPL and the various complications (obstetric, pregnancy, preterm, stillbirth, preeclampsia, placental rupture; thrombosis, arterial, venous). Included only studies that reported the frequency of the different aPL

separating between different outcomes associated with placental insufficiency, Andreoli et al. reported a median frequency of $17 \%$ and $2 \%$ for aCL and LAC in pregnancies with intrauterine growth restriction (IUGR), while in preeclampsia, the median frequency was $3 \%, 5 \%$, and $7 \%$ for aCL, anti- $\beta_{2}$ GPI, and LAC, respectively [34•]. In more recent studies, the overall frequency of aPL in women of preeclampsia ranged between 11 and 35\% [36, 39]. Higher median frequencies were seen in eclampsia in Andreoli review and up to 53\% of LAC positivity among patients with HELLP syndrome [34•]. Similarly, Neagoe et al. found that 21/123 (17.1\%) of women with preeclampsia met APS criteria and the prevalence of APS was even higher in women with HELLP syndrome (33.3\%) [40].

Further epidemiological studies are still needed to clarify exactly how much pregnancy morbidity can be attributed to APS, especially for risk stratification, prevention, and treatment of patients with APS obstetric manifestations. 


\section{Venous Thromboembolism and Prevalence of Antiphospholipid Antibodies}

Among all the manifestations of APS, venous thromboembolism (VTE) is the most frequent. In a recent crosssectional population-based study performed in Canada, 491 incident patients with unprovoked VTE between ages 18 and 50 met the revised Sapporo criteria for APS. Of these, $59.1 \%$ were single positive for aPL while $25 \%$ and $15.9 \%$ were double and triple positive, respectively. Only 10 patients $(22.7 \%)$ had a known associated autoimmune disease, $4(9 \%)$ had other risk factors for thrombosis and $36.4 \%$ were on oral contraceptives [41•0]. Similarly, in a prospective cohort of 307 patients with first unprovoked VTE, $8.9 \%$ had the same positive aPL on more than one occasion, meeting criteria for APS [42]. A review observed that around $9.5 \%$ of patients with VTE had positive aPL; however, most of the studies included did not differentiate between provoked and unprovoked VTE and APS was not confirmed in most of the cases [34•].

\section{Arterial Events and Prevalence of Antiphospholipid Antibodies}

Arterial thromboembolism (ATE) is less common than VTE but can be life-threatening. The cerebral arteries are the most frequently involved in APS. Although less frequently, APS patients are at increased risk of myocardial infarction (MI), renal artery thrombosis, mesenteric ischemia, retinal artery thrombosis, and limb ischemia due to arterial thrombosis.

There are multiple studies evaluating the frequency of aPL and APS among patients with cerebrovascular disease, especially among young patients. One study observed that in patients $<69$ years of age with their first episode of stroke, 22\% met criteria for APS [43]. Supporting these facts, a populationbased study, reported a positive aCL antibody or LAC in $42.1 \%$ of women less than 44 years old with a stroke. A relative odds of stroke in women with aCL antibody or LAC was found to be 1.87 (95\% CI 1.24 to $2.83 ; P=0.0027$ ) [44]. Consistently, in the RATIO study, a multicentric case-control population-based study evaluating women aged less than 50 with a cardiovascular event (CVE), presence of LAC, aCL $\mathrm{IgG}$, and anti- $\beta_{2}$ GPI antibodies was observed in $17 \%, 3.5 \%$, and $2.3 \%$ of 175 women with stroke, respectively [45]. A meta-analysis that pooled data from 5217 young patients with a cardiovascular event (CVE) and healthy controls from 43 studies found an overall aPL frequency of $17.4 \%$ (range 5$56 \%$ ) among patients with any CVE, $11.7 \%$ (range 2-45\%) among patients with TIA, and $17.2 \%$ (range $2-56 \%$ ) in patients with stroke [46•].
Less frequently, MI is seen in $1-5.6 \%$ of APS patients $[6 \cdot \bullet, 14,47-49]$. MI can be the initial manifestation of APS and is a common cause of MI with nonobstructive coronary arteries [50]. Other forms of coronary artery disease, like unstable angina, have also been associated with APS [51]. Urbanus et. al. from the RATIO study found a $3 \%$ prevalence of positive LAC, $1 \%$ of positive aCL IgG, and $1.5 \%$ of positive anti- $\beta_{2}$ GPI among 203 young women with MI [45]. In 805 patients younger than 75 years hospitalized for an MI, Grosso et al. observed prevalence of 10 and $11 \%$ for positive IgG anti- $\beta_{2}$ GPI and IgG aCL antibodies, respectively [52].

\section{Conclusions}

Our understanding of the epidemiology of APS remains limited, and many challenges and gaps in knowledge remain. The estimated incidence and prevalence ranges between 1 and 2 cases per 100,000 and 40 and 50 cases per 100,000, respectively. The mortality of patients with APS is $50-80 \%$ higher than the general population. aPL may be associated with up to $10 \%$ of the cases of obstetric morbidity, arterial events, and venous thromboembolism. The data however remains limited and fraught with methodological issues. The clinical heterogeneity of APS is not fully captured by the current criteria, which can lead to underestimation of the true burden of the disease in the population. Thrombosis and obstetric morbidity are often multifactorial; therefore, attribution of these clinical manifestations to APS can be challenging in some cases, particularly in advanced age, or in the presence of infections and/ or malignancy. Moreover, it remains to be elucidated if the frequency of APS among different racial and ethnic groups is different as is in the case of SLE. Larger population-based studies with diverse racial and ethnic groups are needed. As the classification criteria continues to evolve, it is likely that patients currently undiagnosed or classified differently may be reclassified as APS patients in the future; therefore, our current estimation of APS incidence and prevalence will continue to evolve.

\section{Declarations}

Conflict of Interest Jesse Dabit declares that he has no conflict of interest.

Maria O. Valenzuela- Almada declares that she has no conflict of interest.

Sebastian Vallejo-Ramos declares that he has no conflict of interest.

Alí Duarte-García declares that he has no conflict of interest.

Human and Animal Rights and Informed Consent This article does not contain any studies with human or animal subjects performed by any of the authors. 


\section{References}

Papers of particular interest, published recently, have been highlighted as:

- Of importance

- Of major importance

1. Corban MT, Duarte-Garcia A, McBane RD, Matteson EL, Lerman LO, Lerman A. Antiphospholipid syndrome: role of vascular endothelial cells and implications for risk stratification and targeted therapeutics. J Am Coll Cardiol. 2017;69(18):2317-30.

2. Bobba RS, Johnson SR, Davis AM. A review of the sapporo and revised Sapporo criteria for the classification of antiphospholipid syndrome. Where do the revised sapporo criteria add value? J Rheumatol. 2007;34(7):1522-7.

3. Miyakis S, Lockshin MD, Atsumi T, Branch DW, Brey RL, Cervera $\mathrm{R}$, et al. International consensus statement on an update of the classification criteria for definite antiphospholipid syndrome (APS). J Thromb Haemost. 2006;4(2):295-306.

4. Sciascia S, Amigo MC, Roccatello D, Khamashta M. Diagnosing antiphospholipid syndrome: 'extra-criteria' manifestations and technical advances. Nat Rev Rheumatol. 2017;13(9):548-60.

5. Sciascia S, Sanna G, Murru V, Roccatello D, Khamashta MA, Bertolaccini ML. Anti-prothrombin (aPT) and antiphosphatidylserine/prothrombin (aPS/PT) antibodies and the risk of thrombosis in the antiphospholipid syndrome. A systematic review. Thromb Haemost. 2014;111(2):354-64.

6.• Duarte-García A, Pham MM, Crowson CS, Amin S, Moder KG, Pruthi RK, et al. The Epidemiology of Antiphospholipid Syndrome: A Population-Based Study. Arthritis Rheum. 2019;71(9):1545-52. First population-based epidemiologic study of APS.

7. Luissi ASM, Grande Ratti MF, Posadas Martinez ML, Soriano ER Burden of antiphospholipid syndrome in a Thromboembolic Disease Registry [abstract]. Arthritis Rheum. 2017:69.

8. Hwang JJ, Shin SH, Kim YJ, Oh YM, Lee SD, Kim YH, et al. Epidemiology of Antiphospholipid syndrome in Korea: a nationwide population-based study. J Korean Med Sci. 2020;35(5):e35.

9. Radin M, Sciascia S, Bazzan M, Bertero T, Carignola R, Montabone E, et al. Antiphospholipid syndrome is still a rare disease-estimated prevalence in the Piedmont and Aosta Valley Regions of Northwest Italy: Comment on the Article by DuarteGarcía et al. Arthritis Rheum. 2020;72(10):1774-6.

10. Rodziewicz MDCD, Gulliford M, Hazra M. The epidemiology of the antiphospholipid syndrome in the UK, 1990 - 2016 [abstract]. Arthritis Rheum. 2019;71(suppl 10).

11. Sisó-Almirall A, Kostov B, Martínez-Carbonell E, Brito-Zerón P, Ramirez PB, Acar-Denizli N, et al. The prevalence of 78 autoimmune diseases in Catalonia (MASCAT-PADRIS Big Data Project). Autoimmun Rev. 2020;19(2):102448.

12. Nusbaum JS, Mirza I, Shum J, Freilich RW, Cohen RE, Pillinger $\mathrm{MH}$, et al. Sex differences in systemic lupus erythematosus: epidemiology, clinical considerations, and disease pathogenesis. Mayo Clin Proc. 2020;95(2):384-94.

13. Bertero MT, Bazzan M, Carignola R, Montaruli B, Silvestro E, Sciascia S, et al. Antiphospholipid syndrome in northwest Italy (APS Piedmont Cohort): demographic features, risk factors, clinical and laboratory profile. Lupus. 2012;21(7):806-9.

14. Cervera R, Khamashta MA, Shoenfeld Y, Camps MT, Jacobsen S, Kiss E, et al. Morbidity and mortality in the antiphospholipid syndrome during a 5-year period: a multicentre prospective study of 1000 patients. Ann Rheum Dis. 2009;68(9):1428-32.
15. Somers EC, Marder W, Cagnoli P, Lewis EE, DeGuire P, Gordon $\mathrm{C}$, et al. Population-based incidence and prevalence of systemic lupus erythematosus: the Michigan Lupus Epidemiology and Surveillance program. Arthritis Rheum. 2014;66(2):369-78.

16. Gómez-Puerta JA, Espinosa G, Cervera R. Antiphospholipid Antibodies: From General Concepts to Its Relation with Malignancies. Antibodies (Basel). 2016;5(3).

17. Avcin T, Cimaz R, Silverman ED, Cervera R, Gattorno M, Garay S, et al. Pediatric antiphospholipid syndrome: clinical and immunologic features of 121 patients in an international registry. Pediatrics. 2008;122(5):e1100-7.

18. Ma J, Song H, Wei M, He Y. Clinical characteristics and thrombosis outcomes of paediatric antiphospholipid syndrome: analysis of 58 patients. Clin Rheumatol. 2018;37(5):1295-303.

19. Zamora-Ustaran A, Escarcega-Alarcón RO, Garcia-Carrasco M, Faugier E, Mendieta-Zeron S, Mendoza-Pinto C, et al. Antiphospholipid syndrome in Mexican children. Isr Med Assoc J. 2012;14(5):286-9.

20. Cervera R, Serrano R, Pons-Estel GJ, Ceberio-Hualde L, Shoenfeld $\mathrm{Y}$, de Ramón E, et al. Morbidity and mortality in the antiphospholipid syndrome during a 10-year period: a multicentre prospective study of 1000 patients. Ann Rheum Dis. 2015;74(6): 1011-8.

21. Soybilgic A, Avcin T. Pediatric APS: State of the Art. Curr Rheumatol Rep. 2020;22(3):9.

22. Grimaud F, Yelnik C, Pineton de Chambrun M, Amoura Z, Arnaud L, Costedoat Chalumeau N, et al. Clinical and immunological features of antiphospholipid syndrome in the elderly: a retrospective national multicentre study. Rheumatology (Oxford). 2019;58(6): 1006-10.

23. Manoussakis MN, Tzioufas AG, Silis MP, Pange PJ, Goudevenos $\mathrm{J}$, Moutsopoulos HM. High prevalence of anti-cardiolipin and other autoantibodies in a healthy elderly population. Clin Exp Immunol. 1987;69(3):557-65.

24. Meroni PL, Mari D, Monti D, Coppola R, Capri M, Salvioli S, Tincani A, Gerli R, Franceschi C. Anti-beta 2 glycoprotein I antibodies in centenarians. Exp Gerontol. 2004;39(10):1459-65.

25. Madison JA, Zuo Y, Knight JS. Pediatric antiphospholipid syndrome. Eur J Rheumatol. 2019;7(Suppl 1):1-10.

26. Abdel-Wahab N, Talathi S, Lopez-Olivo MA, Suarez-Almazor ME. Risk of developing antiphospholipid antibodies following viral infection: a systematic review and meta-analysis. Lupus. 2018;27(4):572-83.

27. Harzallah I, Debliquis A, Drénou B. Lupus anticoagulant is frequent in patients with Covid-19. J Thromb Haemost. 2020;18(8): 2064-5.

28. Xiao M, Zhang Y, Zhang S, Qin X, Xia P, Cao W, et al. Antiphospholipid antibodies in critically Ill patients with COVID19. Arthritis Rheum. 2020;72(12):1998-2004.

29. Sène D, Piette JC, Cacoub P. Antiphospholipid antibodies, antiphospholipid syndrome and infections. Autoimmun Rev. 2008;7(4):272-7.

30. Abdel-Wahab N, Tayar JH, Fa'ak F, Sharma G, Lopez-Olivo MA, Yousif A, et al. Systematic review of observational studies reporting antiphospholipid antibodies in patients with solid tumors. Blood Adv. 2020;4(8):1746-55.

31. Pusterla S, Previtali S, Marziali S, Cortelazzo S, Rossi A, Barbui T, et al. Antiphospholipid antibodies in lymphoma: prevalence and clinical significance. Hematol J. 2004;5(4):341-6.

32. Kungwankiattichai S, Nakkinkun Y, Owattanapanich W, Ruchutrakool T. High Incidence of antiphospholipid antibodies in newly diagnosed patients with lymphoma and a proposed aPL predictive score. Clin Appl Thromb Hemost. 2020;26: 1076029620928392 . 
33. Infante-Rivard C, David M, Gauthier R, Rivard GE. Lupus anticoagulants, anticardiolipin antibodies, and fetal loss. A case-control study. N Engl J Med. 1991;325(15):1063-6.

34. Andreoli L, Chighizola CB, Banzato A, Pons-Estel GJ, Ramire de Jesus G, Erkan D. Estimated frequency of antiphospholipid antibodies in patients with pregnancy morbidity, stroke, myocardial infarction, and deep vein thrombosis: a critical review of the literature. Arthritis Care Res. 2013;65(11):1869-73. Comprehensive review of frequency of aPL in population with different APS associated comorbidities.

35. Benson ATA, Grover B, Paluso A, Branch DW. Low frequency of antiphospholipid antibodies in women with recurrent embryonic and pre-embryonic losses. Lupus. 2019;28(1).

36. Foddai SG, Radin M, Cecchi I, Gaito S, Orpheu G, Rubini E, et al. The prevalence of antiphospholipid antibodies in women with late pregnancy complications and low-risk for chromosomal abnormalities. J Thromb Haemost. 2020;18(11):2921-8.

37. Bowman ZS, Wünsche V, Porter TF, Silver RM, Branch DW. Prevalence of antiphospholipid antibodies and risk of subsequent adverse obstetric outcomes in women with prior pregnancy loss. J Reprod Immunol. 2015;107:59-63.

38. Silver RM, Parker CB, Reddy UM, Goldenberg R, Coustan D, Dudley DJ, et al. Antiphospholipid antibodies in stillbirth. Obstet Gynecol. 2013;122(3):641-57.

39. Gibbins KJ, Tebo AE, Nielsen SK, Branch DW. Antiphospholipid antibodies in women with severe preeclampsia and placental insufficiency: a case-control study. Lupus. 2018;27(12):1903-10.

40. Neagoe AMF, Rexhaj E, Rimoldi S, Baumann M, Surbek D, Raio L. The prevalence of antiphospholipid Syndrome in women after preeclampsia a single tertiary care center experience in Switzerland. J Hypertens. 2019;37.

41.• Miranda S, Park J, Le Gal G, Piran S, Kherani S, Rodger MA, et al. Prevalence of confirmed antiphospholipid syndrome in 18-50 years unselected patients with first unprovoked venous thromboembolism. J Thromb Haemost. 2020;18(4):926-30. First populationbased study evaluating the prevalence of aPL and APS in people with first unprovoked VTE.

42. Kearon C, Parpia S, Spencer FA, Baglin T, Stevens SM, Bauer KA, et al. Antiphospholipid antibodies and recurrent thrombosis after a first unprovoked venous thromboembolism. Blood. 2018;131(19): 2151-60.

43. Gašperšič N, Zaletel M, Kobal J, Žigon P, Čučnik S, Šemrl SS, et al. Stroke and antiphospholipid syndrome-antiphospholipid antibodies are a risk factor for an ischemic cerebrovascular event. Clin Rheumatol. 2019;38(2):379-84.

44. Brey RL, Abbott RD, Curb JD, Sharp DS, Ross GW, Stallworth $\mathrm{CL}$, et al. beta(2)-Glycoprotein 1-dependent anticardiolipin antibodies and risk of ischemic stroke and myocardial infarction: the honolulu heart program. Stroke. 2001;32(8):1701-6.

45. Urbanus RT, Siegerink B, Roest M, Rosendaal FR, de Groot PG, Algra A. Antiphospholipid antibodies and risk of myocardial infarction and ischaemic stroke in young women in the RATIO study: a case-control study. Lancet Neurol. 2009;8(11):998-1005.

46. Sciascia S, Sanna G, Khamashta MA, Cuadrado MJ, Erkan D, Andreoli L, et al. The estimated frequency of antiphospholipid antibodies in young adults with cerebrovascular events: a systematic review. Ann Rheum Dis. 2015;74(11):2028-33. Systematic review summarizing the frequency of aPL in patients with CVE.

47. Nazir S, Tachamo N, Lohani S, Hingorani R, Poudel DR, Donato A. Acute myocardial infarction and antiphospholipid antibody syndrome: a systematic review. Coron Artery Dis. 2017;28(4):332-5.

48. Serrano R, Pons-Estel GJ, Espinosa G, Quintana RM, Reverter JC, Tassies D, et al. Long-term follow-up of antiphospholipid syndrome: real-life experience from a single center. Lupus. 2020;29(9):1050-9.
49. García-Carrasco M, Galarza C, Gómez-Ponce M, Cervera R, RojasRodríguez J, Espinosa G, et al. Antiphospholipid syndrome in Latin American patients: clinical and immunologic characteristics and comparison with European patients. Lupus. 2007;16(5):366-73.

50. Stepien K, Nowak K, Wypasek E, Zalewski J, Undas A. High prevalence of inherited thrombophilia and antiphospholipid syndrome in myocardial infarction with non-obstructive coronary arteries: Comparison with cryptogenic stroke. Int J Cardiol. 2019;290:1-6.

51. Hojnik M, George J, Ziporen L, Shoenfeld Y. Heart valve involvement (Libman-Sacks endocarditis) in the antiphospholipid syndrome. Circulation. 1996;93(8):1579-87.

52. Grosso G, Sippl N, Kjellström B, Amara K, de Faire U, Elvin K, et al. Antiphospholipid antibodies in patients with myocardial infarction. Ann Intern Med. 2019;170(4):277-80.

53. Siemens HJ, Gutsche S, Brückner S, Bucsky P, Katus HA. Antiphospholipid antibodies in children without and in adults with and without thrombophilia. Thromb Res. 2000;98(4):241-7.

54. Rapizzi E, Ruffatti A, Tonello M, Piccoli A, Calligaro A, Sfriso P, et al. Correction for age of anticardiolipin antibodies cut-off points. J Clin Lab Anal. 2000;14(3):87-90.

55. Ordi-Ros J, Villarreal J, Monegal F, Sauleda S, Esteban I, Vilardell M. Anticardiolipin antibodies in patients with chronic hepatitis C virus infection: characterization in relation to antiphospholipid syndrome. Clin Diagn Lab Immunol. 2000;7(2):241-4.

56. Sthoeger ZM, Fogel M, Smirov A, Ergas D, Lurie Y, Bass DD, et al. Anticardiolipin autoantibodies in serum samples and cryoglobulins of patients with chronic hepatitis $\mathrm{C}$ infection. Ann Rheum Dis. 2000;59(6):483-6.

57. Brey RL, Stallworth CL, McGlasson DL, Wozniak MA, Wityk RJ, Stern BJ, et al. Antiphospholipid antibodies and stroke in young women. Stroke. 2002;33(10):2396-400.

58. Avcin T, Ambrozic A, Kuhar M, Kveder T, Rozman B. Anticardiolipin and anti-beta(2) glycoprotein I antibodies in sera of 61 apparently healthy children at regular preventive visits. Rheumatology (Oxford). 2001;40(5):565-73.

59. Cabiedes J, Trejo-Hernández J, Loredo-Abdalá A, Castilla-Serna L, López-Mendoza AT, Cordero-Esperón HA, et al. Anti-cardiolipin, anti-cardiolipin plus bovine, or human beta(2)glycoprotein-I and anti-human beta(2)glycoprotein-I antibodies in a healthy infant population. Arch Med Res. 2002;33(2):175-9.

60. Harrison CN, Donohoe S, Carr P, Dave M, Mackie I, Machin SJ. Patients with essential thrombocythaemia have an increased prevalence of antiphospholipid antibodies which may be associated with thrombosis. Thromb Haemost. 2002;87(5):802-7.

61. McIntyre JA, Wagenknech DR, Waxman DW. Frequency and specificities of antiphospholipid antibodies (aPL) in volunteer blood donors. Immunobiology. 2003;207(1):59-63.

62. Palomo I, Alarcón M, Sepulveda C, Pereira J, Espinola R, Pierangeli S. Prevalence of antiphospholipid and antiplatelet antibodies in human immunodeficiency virus (HIV)-infected Chilean patients. J Clin Lab Anal. 2003;17(6):209-15.

63. Font C, Vidal L, Espinosa G, Tàssies D, Monteagudo J, Farrús B, et al. Solid cancer, antiphospholipid antibodies, and venous thromboembolism. Autoimmun Rev. 2011;10(4):222-7.

64. Chayoua W, Kelchtermans H, Moore GW, Musiał J, Wahl D, de Laat B, et al. Identification of high thrombotic risk triple-positive antiphospholipid syndrome patients is dependent on anticardiolipin and anti- $\beta 2$ glycoprotein I antibody detection assays. J Thromb Haemost. 2018;16(10):2016-23.

Publisher's Note Springer Nature remains neutral with regard to jurisdictional claims in published maps and institutional affiliations. 